\title{
A Study on Different Types Uighur Female Middle School Students' Physical Fitness and Its Influencing Factors in Urumqi
}

\author{
Wenmei Dong ${ }^{1, a}$ and Hui Wang ${ }^{2, b}$ \\ ${ }^{1}$ Physical Education Department of Minzu University, Beijing ,China \\ 2 Physical Education Department of Xinjiang Normal University, Urumqi ,China \\ adongwenm@163.com, b1006363016@qq.com
}

Keywords: Physical fitness; Uighur; Female middle school students

\begin{abstract}
This research chose six schools in Urumqi, each of which was on behalf of exemplary senior middle school of Xinjiang Uyghur autonomous region, general middle school and rural middle school. The female students in eighth grade were selected as research object and were tested in the same grade and area. Using the test method and ANOVA analysis method, two comparison method of SPSS 19.0, the research analyzed the physical fitness influencing factors on the basis of real data and attending lectures and teachers interview. Through comparative significant difference, the research try to find the main facts affecting physical fitness. The results indicated the physical fitness of rural middle school is better than that of common middle school and key middle school. This showed that students ' physical fitness were related to school stress. Moreover, the physical fitness of Uighur female middle school students were better than that of Han nationality, the reason of which were related to the parents of Uighur let the children grow up freely and less study pressure.
\end{abstract}

\section{Introduction}

The physical health of adolescent is related to the rise and fall of the Chinese nation. In recent years, the physical fitness of adolescent continued to decline, which gave rise to the government's attention. To improve the physical health of adolescent, the government has formulated and introduced a series of policies and measures. Urumqi is not only the capital of the Xinjiang Autonomous Region, but also a multi-ethnic city. Based on the data of physical fitness, it is of great significance to study the level and influencing factors of physical fitness of adolescents in this region.

In the search of China national knowledge infrastructure, the study on the physical fitness of adolescents in Xinjiang focused on comparative study among different national minority and the method of statistical analysis method was used SPSS general description. One the other hand, the study focused on the factors influencing physical fitness and the method was used qualitative analysis. In the search of Proquest and Elsevier, the study on the physical fitness focused on the special population. In view of the current situation of the physical fitness of adolescents in Xinjiang, the Chinese scholars have provided the analysis of the large sample size from the view of each national minority and the references for the follow-up research. However, the overall research tended to be a descriptive analysis of the large sample population, which were lack of more detailed comparative analysis.

Selecting six middle schools in Urumqi representing three levels the advanced middle school, the common middle school and the rural middle school, the researchers tested the physical fitness of Uighur females and randomly listened to one class and interviewed with three teachers Each school. The research attempted to solve three problems:1. What are the real physical fitness situation of the Uighur females in six middle schools ? 2. Are there any significant differences about the physical fitness of the Uighur females among the three type of school? 3. Whether the significant differences were related to the types of school? Can we find out the factors affecting physical fitness from the causes of differences? 


\section{Research Object and Method}

Research Object. The eighth grade of the Uighur females in six middle schools were chosen as the research object. The two advanced middle schools were Affiliated Middle School of Xinjiang Normal University and Urumqi 98th Middle School. The two common middle schools were Urumqi Second Middle School and Urumqi Seventh Middle School. The two rural middle schools were Urumqi 87th Middle School and Urumqi Aike Middle School. The data were collected from the testing in 2016.

\section{Research Methods}

Test Method. According to the test items in 《National Student Physical Health Standard》, females in eighth grade take part in test of 50 meters, standing long jump, 800 meters, sits-up per minute and sitting body flexion.

Mathematical Statistics. The research used Spss19.0 to analyze the testing dada from the three middle schools. The ANOVA analysis was used to test whether there are any significant differences in the physical fitness of the students among the three schools. The Post Hoc Test was used to compare the differences between the two groups.

Interview. The research chose three teachers each school to participate in the interview. At the same time, the researcher listened to physical education to find the factors influencing the physical fitness.

\section{Research Result and Analysis}

\section{Analysis on the Basic Situation of Uighur Females in the Advanced Middle School}

Table 1 the basic situation of uighur females in the two advanced middle schools

\begin{tabular}{|c|c|c|c|c|c|c|}
\hline School & Item & Sample & Average & $\begin{array}{l}\text { Excellent } \\
\text { Rate }\end{array}$ & $\begin{array}{l}\text { Good } \\
\text { Rate }\end{array}$ & $\begin{array}{l}\text { Pass } \\
\text { Rate }\end{array}$ \\
\hline \multirow{5}{*}{ Affiliated } & $\begin{array}{c}\text { standing long jump } \\
(\mathrm{cm})\end{array}$ & 34 & $161(17)$ & $9.8 \%$ & $17.6 \%$ & $95.3 \%$ \\
\hline & $\begin{array}{l}\text { sitting body } \\
\text { flexion }(\mathrm{cm})\end{array}$ & 34 & $10.4(5.1)$ & $3.9 \%$ & $14.7 \%$ & $89.2 \%$ \\
\hline & 50 meters $(\mathrm{s})$ & 34 & $8.76(0.88)$ & $32.4 \%$ & $70.6 \%$ & $97 \%$ \\
\hline & sit-up (n) & 34 & $34(5)$ & $2.9 \%$ & $11.8 \%$ & $100 \%$ \\
\hline & 800 meters (s) & 34 & $266(0.38)$ & $40.1 \% \%$ & $47.1 \%$ & $98 \%$ \\
\hline \multirow{5}{*}{ 98th } & $\begin{array}{l}\text { standing long jump } \\
(\mathrm{cm})\end{array}$ & 136 & $178(27.9)$ & $36.3 \%$ & $50.7 \%$ & $90 \%$ \\
\hline & $\begin{array}{l}\text { sitting body } \\
\text { flexion }(\mathrm{cm})\end{array}$ & 136 & $16.1(9.23)$ & $41.2 \%$ & $46.3 \%$ & $89.7 \%$ \\
\hline & 50 meters (s) & 136 & $8.54(0.68)$ & $30.9 \%$ & $69.9 \%$ & $100 \%$ \\
\hline & sit up (n) & 136 & $32(9)$ & $0 \%$ & $23.8 \%$ & $83.8 \%$ \\
\hline & 800 meters (s) & 136 & $261(0.45)$ & $14 \%$ & $17.6 \%$ & $87.5 \%$ \\
\hline
\end{tabular}

From table 1, we can see the results that the average of uighur female's in eighth grade in 98th was $32 \pm 9$, the good rate was $23.8 \%$, the excellent rate was $0 \%$, from which we found that the uighur female had poor waist strength.The average of 800 meters was $4{ }^{\prime} 35^{\prime \prime} \pm 0.45$, the good rate was $17.6 \%$, from which we found endurance exercises need to be strengthed.Moreover, the results of sitting body flexion, standing long jump were basically qualified while the result of 50 meters was better. 
Analysis:Through listening to P.E,interviewing the teachers, we know Urumqi 98th Middle School is the biggest school in Midong district and there are sixty to seventy students in each class. Limited to traditional thinking, most of the uighur female think that female should not do exercise, but recently they change this idea and take part in exercise. At the same time,we find there is almost no strength exercise in the P.E. and Extracurricular sports activities.

From table 1, we can see the results that the average of uighur female's in eighth grade in Affiliated was $34 \pm 5$, the good rate was $11.8 \%$, the excellent rate was $2.9 \%$, from which we found that the uighur female had poor waist strength. The average of sitting body flexion was $10.4 \pm 5.1$, the good rate was $14.7 \%$, the excellent rate was $3.9 \%$,from which we found flexibility exercises need to be strengthen. Moreover, the results of 50 meters, 800 meters and standing long jump were good.

Analysis: Through listening to P.E,interviewing the teachers, we know the main teaching content focus on high school entrance examination sports such as soccer,basketballand volleyball.Therefore, there is almost no strength and flexibility exercise in the P.E.

\section{Analysis on the Basic Situation of Uighur Females in the Common Middle School}

Table 2 the basic situation of uighur females in the two common middle schools

\begin{tabular}{|c|c|c|c|c|c|c|}
\hline School & Item & Sample & Average & $\begin{array}{c}\text { Excellent } \\
\text { Rate }\end{array}$ & $\begin{array}{c}\text { Good } \\
\text { Rate }\end{array}$ & $\begin{array}{c}\text { Pass } \\
\text { Rate }\end{array}$ \\
\hline \multirow{5}{*}{ Second } & $\begin{array}{c}\text { standing long jump } \\
\text { (cm) }\end{array}$ & 133 & $178(13)$ & $9.8 \%$ & $17.6 \%$ & $85.3 \%$ \\
\cline { 2 - 7 } & $\begin{array}{c}\text { sitting body } \\
\text { flexion(cm) }\end{array}$ & 133 & $15.3(4.5)$ & $5.9 \%$ & $14.7 \%$ & $94.1 \%$ \\
\cline { 2 - 7 } & 50 meters (s) & 133 & $8.85(0.8)$ & $14.2 \%$ & $41.8 \%$ & $95.5 \%$ \\
\cline { 2 - 7 } & sit-up (n) & 133 & $41(6)$ & $2.9 \%$ & $12.8 \%$ & $100 \%$ \\
\cline { 2 - 8 } & $\begin{array}{c}800 \text { meters (s) } \\
\text { Seventh }\end{array}$ & 133 & $255(0.42)$ & $41.2 \%$ & $47.1 \%$ & $100 \%$ \\
\cline { 2 - 8 } & $\begin{array}{c}\text { standing long jump } \\
\text { (cm) }\end{array}$ & 26 & $158(15)$ & $0 \%$ & $19.2 \%$ & $80.8 \%$ \\
\cline { 2 - 8 } & fltting body & 26 & $9.91(5.04$ & $3.8 \%$ & $7.7 \%$ & $100 \%$ \\
\cline { 2 - 7 } & 50 meters (s) & 26 & $9.72(0.75$ & $0 \%$ & $11.5 \%$ & $96.2 \%$ \\
\cline { 2 - 7 } & sit-up (n) & 26 & $25(8)$ & $0 \%$ & $0 \%$ & $57.7 \%$ \\
\cline { 2 - 7 } & 800 meters (s) & 26 & $269(0.56)$ & $19.2 \%$ & $26.9 \%$ & $80.8 \%$ \\
\hline
\end{tabular}

From table 2, we can see the results of uighur female's physical fitness in Urumqi Seventh Middle School, among which the results of sit-up and standing long jump were poor, the results of 800 meters ,the results of sitting body flexion and the results of were 50 meters were in general. The average sit-up of uighur female's in eighth grade in seventh was $25 \pm 8$, the good rate was $0 \%$, the excellent rate was $0 \%$, from which we found that the uighur female in seventh had poor waist strength. The average of sitting body flexion was $9.91 \pm 5.04$, the good rate was $7.7 \%$, from which we found flexibility exercises need to be strengthed.

Analysis:Through listening to P.E,interviewing the teachers, we know the main the teaching content also focus on high school entrance examination sports and physical education teachers take school security work, which affect the quality of physical education because of time conflicts between the two 
types of work.

From table 2, we can see the results of uighur female's physical fitness in Urumqi Second Middle School, among which the results of sitting body flexion and standing long jump were poor, the results of the results of sit-up were in general while the results of 50 meters and 800 meters were good.The average of sitting body flexion was $15.3 \pm 4.5$, the good rate was $14.7 \%$, the excellent rate was $5.9 \%$, from which we found that the uighur female in second had poor flexibility. The average of standing long jump was $178 \pm 13$, the good rate was $17.6 \%$, the excellent rate was $9.8 \%$, from which we found that the uighur female in second had poor lower limbs strength.

Analysis: Because of the long winter and the limitations of sites, the teaching content focus on physical fitness. Through observation and interview, physical education and large class activities carry out normally.

\section{Analysis on the Basic Situation of Uighur Females in the Rural Middle School}

Table 3 the basic situation of uighur females in the two rural middle schools

\begin{tabular}{|c|c|c|c|c|c|c|}
\hline Schoo & Item & Sample & Average & $\begin{array}{l}\text { Excellent } \\
\text { Rate }\end{array}$ & $\begin{array}{c}\text { Good } \\
\text { Rate }\end{array}$ & $\begin{array}{l}\text { Pass } \\
\text { Rate }\end{array}$ \\
\hline \multirow{5}{*}{87 th } & $\begin{array}{l}\text { standing long jump } \\
(\mathrm{cm})\end{array}$ & 133 & $177(21)$ & $14.7 \%$ & $32.4 \%$ & $97.1 \%$ \\
\hline & $\begin{array}{l}\text { sitting body } \\
\text { flexion }(\mathrm{cm})\end{array}$ & 133 & $\begin{array}{c}12.69(8.5 \\
)\end{array}$ & $14.7 \%$ & $29.4 \%$ & $88.2 \%$ \\
\hline & 50 meters $(\mathrm{s})$ & 133 & $\begin{array}{c}8.71(0.69 \\
)\end{array}$ & $11.8 \%$ & $64.7 \%$ & $100 \%$ \\
\hline & sit-up (n) & 133 & $26(10)$ & $2.9 \%$ & $2.9 \%$ & $64.7 \%$ \\
\hline & 800 meters (s) & 133 & $225(0.21)$ & $29.4 \%$ & $73.5 \%$ & $100 \%$ \\
\hline \multirow{5}{*}{ Aike } & $\begin{array}{c}\text { standing long jump } \\
(\mathrm{cm})\end{array}$ & 75 & $158(12)$ & $2.4 \%$ & $19.2 \%$ & $79.5 \%$ \\
\hline & $\begin{array}{l}\text { sitting body } \\
\text { flexion }(\mathrm{cm})\end{array}$ & 75 & $13.4(6.8)$ & $16.4 \%$ & $28.8 \%$ & $91.8 \%$ \\
\hline & 50 meters $(\mathrm{s})$ & 75 & $\begin{array}{c}8.78(0.69 \\
)\end{array}$ & $20.5 \%$ & $46.6 \%$ & $100 \%$ \\
\hline & sit-up (n) & 75 & $30(7)$ & $0 \%$ & $6.8 \%$ & $88.7 \%$ \\
\hline & 800 meters $(\mathrm{s})$ & 75 & $252(0.47)$ & $39.1 \%$ & $60.3 \%$ & $97.3 \%$ \\
\hline
\end{tabular}

From table 3, we can see the results of uighur female's physical fitness in Urumqi 87th Middle School, among which the results of sit-up were poor, the results of sitting body flexion and standing long jump were in general while the results of 50 meters and 800 meters were good.The average of sit-up was $26 \pm 10$, the good rate was $2.9 \%$, from which we found that the uighur female in 87 th had poor had poor waist strength.

Analysis:Through interviewing,we konw the teaching content focus on high school entrance examination sports, which cause few strength exercises to be arranged.Moreover, as students come from the countryside, they ride bicycle or walk to school, which increase the time of physical activities.

From table 3, we can see the results of uighur female's physical fitness in Urumqi Aike Middle School, among which the results of sit-up and standing long jump were poor, the results of sitting body flexion were in general while the results of 50 meters and 800 meters were good. The average of sit-up 
was $30 \pm 7$, the good rate was $6.8 \%$, the excellent rate was $0 \%$; the average of standing long jump was $158 \pm 12$, from which we found that the uighur female in Aike had poor waist and lower limb strength.

Analysis: Urumqi Aike Middle School has similar aspects with Urumqi 87th Middle School, for example,the teaching content focus on high school entrance examination sports and the students ride bicycle or walk to school.

\section{Multiple Comparisons and Influencing factors Analysis on Uighur Female's Physical Fitness}

Table 4 ANOVA Analysis among Boys Physical Fitness

\begin{tabular}{|c|c|c|c|c|c|c|}
\hline Item & & Sum of square & $\mathrm{df}$ & mean square & $\mathrm{F}$ & Sig. \\
\hline \multirow{2}{*}{$\begin{array}{c}50 \\
\text { meters }\end{array}$} & $\begin{array}{l}\text { between } \\
\text { group }\end{array}$ & 13.739 & 2 & 6.864 & 10.001 & .000 \\
\hline & $\begin{array}{l}\text { group within } \\
\text { the statistics }\end{array}$ & 297.876 & 434 & .686 & & \\
\hline \multirow{2}{*}{$\begin{array}{l}\text { sitting } \\
\text { body } \\
\text { flexion }\end{array}$} & $\begin{array}{l}\text { between } \\
\text { group }\end{array}$ & 209.215 & 2 & 104.167 & 1.960 & .142 \\
\hline & $\begin{array}{l}\text { group within } \\
\text { the statistics }\end{array}$ & 23160.684 & 434 & 53.366 & & \\
\hline \multirow{2}{*}{ sit-up } & $\begin{array}{l}\text { between } \\
\text { group }\end{array}$ & 622.398 & 2 & 3111.199 & 38.710 & .000 \\
\hline & $\begin{array}{l}\text { group within } \\
\text { the statistics }\end{array}$ & 34881.798. & 434 & 80.373 & & \\
\hline \multirow{2}{*}{$\begin{array}{l}\text { standing } \\
\text { long } \\
\text { jump }\end{array}$} & $\begin{array}{l}\text { between } \\
\text { group }\end{array}$ & 50855.858 & 2 & 25427.929 & 12.312 & .000 \\
\hline & $\begin{array}{l}\text { group within } \\
\text { the statistics }\end{array}$ & 896347.549 & 434 & 2065.317 & & \\
\hline \multirow{2}{*}{$\begin{array}{c}800 \\
\text { meters }\end{array}$} & $\begin{array}{l}\text { between } \\
\text { group }\end{array}$ & 17.874 & 2 & 8.937 & 41.238 & .000 \\
\hline & $\begin{array}{l}\text { group within } \\
\text { the statistics }\end{array}$ & 94.052 & 434 & .217 & & \\
\hline
\end{tabular}

As it was seen from table 4, there was significant difference among uighur female' s 50 meters results, $\mathrm{F}$ value was 10.0001 , sig. value was $0.000, \mathrm{P}<0.05$. There was significant difference among uighur female's sit-up results, $\mathrm{F}$ value was 38.710 , sig. value was $0.000, \mathrm{P}<0.05$. There was significant difference among uighur female's 800 meters results, $\mathrm{F}$ value was 8.973, sig. value was $0.000, \mathrm{P}<0.05$. There was significant difference among uighur female's standing long jump results, F value was 12.312, sig. value was $0.000, \mathrm{P}<0.05$.

Using the method of comparison between the two of significant difference items, we can see from table 5 that there is significant difference of 50 meters between the common and other two types of schools, the sig. value was respectively $0.000,0.024, \mathrm{p}<0.05$, the 50 results of the rural are better. Through the comparison of 800 meters, we find out that there is significant difference among the three types of schools and the results of the rural are better. Meanwhile, there is significant difference of sit-up among the three types of schools, the sig. value respectively was $0.000 、 0.088, p<0.05$, the results of the advanced are better than the common, but there was no significant difference between the advance and the rural. There is significant difference of standing long jump between the common and the other two types of schools, the sig.value respectively was $0.000,0.012 p<0.05$, the results of the advance and the rural are better.

From the above analysis, we can be see that the similarity of three types of school was the teaching content focused on high school entrance examination sports. The total test results in rural middle school 
were better than that of other two types of schools. The reason existed in the pressure of the advanced middle schools which made the students spend more time studying, less time participating in physical activities. From the view of school, the key to solving the problem is to reduce the burden of students, especially do not take up the students physical education, extracurricular sports activities and after-school physical exercise time.

Table 5 Comparison Between the Two of Significant Difference Items

\begin{tabular}{|c|c|c|c|c|c|}
\hline $\begin{array}{l}\text { Dependent } \\
\text { variable }\end{array}$ & School(I) & School(J) & $\begin{array}{c}\text { Mean } \\
\text { difference } \\
(\mathrm{I}-\mathrm{J})\end{array}$ & $\begin{array}{l}\text { Standard } \\
\text { error }\end{array}$ & Sig. \\
\hline \multirow{6}{*}{$\begin{array}{c}50 \\
\text { meters }\end{array}$} & \multirow{2}{*}{ Advanced } & Common & $-.40814^{*}$ & .09140 & .000 \\
\hline & & Rural & -.17430 & .10194 & .088 \\
\hline & \multirow{2}{*}{ Common } & Advanced & $.40814 *$ & .09140 & .000 \\
\hline & & Rural & $.23384 *$ & .10330 & .024 \\
\hline & \multirow{2}{*}{ Rural } & Advanced & .17430 & .10194 & .088 \\
\hline & & Common & $-.23384^{*}$ & .10330 & .024 \\
\hline \multirow{6}{*}{ sit-up } & \multirow{2}{*}{ Advanced } & Common & $-5.533 *$ & .989 & .000 \\
\hline & & Rural & 4. $079 *$ & 1.103 & .000 \\
\hline & \multirow{2}{*}{ Common } & Advanced & $5.533^{*}$ & .989 & .000 \\
\hline & & Rural & $9.611^{*}$ & 1.118 & .000 \\
\hline & \multirow{2}{*}{ Rural } & Advanced & $-4.079 *$ & 1.103 & .000 \\
\hline & & Common & -9.611 & 1.118 & .000 \\
\hline \multirow{6}{*}{$\begin{array}{l}\text { standing long } \\
\text { jump }\end{array}$} & \multirow{2}{*}{ Advanced } & Common & $24.836^{*}$ & 5.014 & .000 \\
\hline & & Rural & 10.519 & 5.592 & .061 \\
\hline & \multirow{2}{*}{ Common } & Advanced & $-24.836^{*}$ & 5.014 & .000 \\
\hline & & Rural & $-14.317 *$ & 5.667 & 0.012 \\
\hline & \multirow{2}{*}{ Rural } & Advanced & -10.519 & 5.592 & .061 \\
\hline & & Common & $-14.317^{*}$ & 5.667 & 0.012 \\
\hline \multirow{6}{*}{800 meters } & \multirow{2}{*}{ Advanced } & Common & $.30492 *$ & .05136 & .000 \\
\hline & & Rural & $.50215^{*}$ & .05728 & .0001 \\
\hline & \multirow{2}{*}{ Common } & Advanced & $.30492 *$ & .05136 & .000 \\
\hline & & Rural & $-.19723^{*}$ & .05805 & .001 \\
\hline & \multirow{2}{*}{ Rural } & Advanced & $.50215^{*}$ & .05728 & .0001 \\
\hline & & Common & $-.19723^{*}$ & .05805 & .001 \\
\hline
\end{tabular}




\section{Summary}

The common physical fitness of uighur female was the poor of strength. The main teaching content focused on high school entrance examination sports, which resulted in a single teaching content. Using the method of comparison between the two of significant difference items, we found that the rural was better, which indicated that the key to solving the problem is to reduce the burden of students, especially do not take up the students physical education, extracurricular sports activities and after-school physical exercise time.

\section{Acknowledgements}

This work was financially supported by the State Ethnic Affairs Commission of China for "Support Program for the Young and Middle-Aged Talents" 2014;2017 Minzu University of China "The construction of a world-class university in the central university and guiding Characteristic development special funds "

\section{Reference}

[1] S.Jun, Research on the Physical Health of Students in the Rural Middle School in Lian Yungang City,Journal of Sports Science(2007),25-30

[2] Chinese Student Physical and Health Study Group, A Report on Chinese Students' Physical and Health in 2005, Beijing High Level Education Press,2008.

[3] H.B.,Wei, Study on the Students' Physical and Health of Xibo nationality in Xinjiang Province ,Master Thesis of Xinjiang Normal University,2010

[4] National Student Constitutional Health Standard. (Revised in 2014) 